\title{
IMPLICATIONS OF FORMAL AND NON-FORMAL ISLAMIC EDUCATION INSTITUTIONS IN INDONESIA ON CHILDREN'S MORALS
}

\author{
Umi Hanifah, Inu Sujanah, Anis Nur Diah Rohmawati, Maisyanah \\ Faculty of Tarbiyah, Institut Agama Islam Negeri Kudus \\ Jl. Gondangmanis, Kudus, Central Java, Indonesia. 59322 \\ E-mail: mihanhanifah18@gmail.com
}

\begin{abstract}
Education is not a strange thing anymore. After the establishment of schools for the people of Indonesia, then develop and become several levels and some parts in education. Not only schools are educational for children, but education is divided into formal education, Non-Formal education, and InFormal education. Formal education is also divided into several levels. There are an elementary school or Madrasah Ibtidaiyah, Junior High School or Madrasah Tsanawiyah, vocational or secondary middle school, or Madrasah Aliyah. In non-formal education, there are various types and levels, informal learning that comes from the community or the surrounding environment, education such as Koran in mosques, and diverse other nonformal education, which now has many pursuivants in the community. Often we find the understanding of general and specific education, such as Islamic education, that education is a process that is done to change one's behavior (morality) to be better. The method of education does not serve as formal education. Some aspects need to be completed through non-formal education such as Akhlakul Karimah, deepen the knowledge of religion and hone the skills that have been able to develop it as a useful thing. Formal educational education that is implemented deliberately planned and systematic to help prepare students' potential and non-formal education is present as complementary, reinforcing, and upbringing of its formal education. In the implementation of education, the process should be neatly packaged and supported by a positive environment. Thus the results achieved are as expected.
\end{abstract}

Keywords: Islamic education, formal education, moral, non-formal

\begin{abstract}
Abstrak: Perkembangan dunia pendidikan terus meningkat. Setelah didirikannya sekolah untuk masyarakat Indonesia, kemudian berkembang menjadi beberapa jenjang dan sebagian dalam dunia pendidikan. Tidak hanya sekolah yang mendidik anak, tetapi pendidikan dibagi menjadi pendidikan formal, pendidikan nonformal, dan pendidikan informal. Pendidikan formal juga dibagi menjadi beberapa jenjang. Ada Sekolah Dasar atau Madrasah Ibtidaiyah, Sekolah Menengah Pertama atau Madrasah Tsanawiyah, Sekolah Menengah Kejuruan atau Sekolah Menengah Pertama, atau Madrasah Aliyah. Dalam pendidikan nonformal terdapat berbagai jenis dan jenjang, pembelajaran informal yang berasal dari masyarakat atau lingkungan sekitar, pendidikan seperti mengaji di masjid, dan beragam pendidikan nonformal lainnya, yang kini banyak diminati di masyarakat. Seringkali kita menemukan pengertian pendidikan umum dan khusus, seperti pendidikan Islam, bahwa pendidikan merupakan proses yang dilakukan untuk mengubah perilaku (akhlak) seseorang menjadi lebih baik. Metode pendidikan tidak dijadikan sebagai pendidikan formal. Beberapa aspek yang perlu diselesaikan melalui pendidikan nonformal seperti Akhlakul Karimah, memperdalam ilmu agama dan mengasah ketrampilan yang telah mampu mengembangkannya menjadi hal yang bermanfaat. Pendidikan pendidikan formal yang dilaksanakan dengan sengaja dan sistematis untuk membantu mempersiapkan potensi peserta didik dan pendidikan nonformal hadir sebagai pelengkap, penguat, dan pembinaan dari pendidikan formalnya. Dalam penyelenggaraan pendidikan, prosesnya harus dikemas dengan rapi dan didukung oleh lingkungan yang positif. Dengan demikian hasil yang dicapai sesuai dengan yang diharapkan.
\end{abstract}

Kata Kunci: moral, non-formal, pendidikan formal, pendidikan Islam

\section{Introduction}

Education is one of the things that must be carried out by all individuals. There are several types of educational dimensions one of the spiritual dimension which is a way to teach or improve human attitudes and behavior in society. Education in this case is not just a transfer of knowledge, but also by giving examples of good behavior from educators to students to be created as moral students in society. Islamic education is a process to change the behavior of individuals in personal life in society and the surrounding environment. With the existence of Islamic education that regulates all human behavior to become humans who have a high degree so that they worship well to God. Because with the rules that govern human behavior, this also makes a human being have a direction and purpose in his life. Islamic education 
is defined as the process of transformation and internalization of science and values in students through the growth and development of their natural potential to achieve the perfection of life in all its aspects (Awwaliyah \& Baharun, 2018).

In this millennial era, there are many deviant behaviors in social life. Many children or even adults do not have good behavioral or moral patterns in society. Social misbehavior of juvenile delinquency such as drinking, stealing to lying are often found in the community. If these conditions continue to be allowed then the next young generation will be chaotic. There is no hope to keep the next young generation from being a role model for the surrounding environment.

The purpose of writing articles is to broaden knowledge about education in Indonesia. Not only education that has a curriculum, but it turns out that after reading this journal, readers are expected to know that education is not only that, but there is also non-formal education that comes from the community and informal education that comes from the family.

\section{Understanding the Islamic education environment}

Education is a process of important social activities that serves to transform the state of a society towards a better state. The relationship between education and social conditions is very close, so education may experience a process of specialization and institutionalization in accordance with the needs of complex and modern societies (Mahmud, 2011). Education is also an effort to foster, establish, direct, educate, and train the training aimed at all students formally, in formal and non-formal.

In the Law of the Republic of Indonesia Number 20 of 2003 Concerning the National Education System in general provisions, it is stated that education is a conscious and planned effort to realize learning arrangements in the learning process so that students actively develop their potential, personality, intelligence, noble character, and skills which is needed by himself, society, nation and state.

According to Abuddin Nata, the study of the Islamic Education Environment (tarbiyyah Islamiyyah) is usually implicitly integrated with the discussion of various educational environments. Nevertheless, it can be understood that the Islamic Education Environment is an environment in which there are Islamic characteristics that enable the implementation of Islamic education properly (Suhada, 2017).

1. Formal Islamic Education

Formal education is a structured and level of education consisting of basic, secondary and tertiary education. Formal education is education that is carried out deliberately, planned and systematically to help develop the potential of learners. Juridical Islamic education is expressed in government regulations stating Madrasah Ibtidaiyah (MI), Madrasah Tsanawiyah (MTS), Madrasah Aliyah (MA) (Darlis, 2017).

The value of character education that has been formulated by the Ministry of National Education, namely: religious, honest, tolerance, discipline, hard work, creative, independent, democratic, curiosity, nationalism, love of the motherland, appreciation of achievement, friendly/communicative, love of peace, joy of reading, care for the environment, social care and responsibility (Aini, 2014). The values of character education and their description can be seen in Table 1.

Table 1. Values and descriptions of character education

\begin{tabular}{ll}
\hline \multicolumn{1}{c}{ Value } & $\begin{array}{l}\text { Description } \\
\text { Religious }\end{array}$ \\
\hline Honest & $\begin{array}{l}\text { Attitudes and behaviors that are obedient in carrying out the teachings of religious } \\
\text { beliefs, tolerant of the implementation of worship and harmonious life as fellow } \\
\text { religious people }\end{array}$ \\
\hline Tolerance & $\begin{array}{l}\text { Attitude that is in a person who can guarantee whether that person can be trusted } \\
\text { or not }\end{array}$ \\
\hline Discipline & Behavior that shows discipline in various rules and regulations \\
\hline Hard Work & Behavior that shows earnest effort in achieving something achievement \\
\hline Creative & Think and do something new \\
\hline Independent & Has the nature of not being dependent on others \\
\hline
\end{tabular}




\begin{tabular}{|c|c|}
\hline Democratic & $\begin{array}{l}\text { The mindset, attitude and action that assesses the rights and obligations of himself } \\
\text { and others }\end{array}$ \\
\hline Curiosity & $\begin{array}{l}\text { An attempt to understand or know deeply from something that is learned, heard } \\
\text { and seen }\end{array}$ \\
\hline Spirit of nationality & Prioritizing the interests of the nation and state compared to individual matters \\
\hline Love the country & $\begin{array}{l}\text { Attitudes that show loyalty to the environment, social, culture, economy and } \\
\text { politics of the nation }\end{array}$ \\
\hline Reward achievements & An action that drives him to get something useful for the community \\
\hline Friendly / communicative & $\begin{array}{l}\text { An action that shows the feeling of being happy to talk, happy to get along and } \\
\text { happy to work with others }\end{array}$ \\
\hline Peace of Love & Actions that make others feel happy and safe for their presence \\
\hline Likes to read & Provide time to read something that is useful for him \\
\hline Care for the Environment & $\begin{array}{l}\text { Actions attempt to prevent damage to the natural environment and its } \\
\text { surroundings and repair the damage that has occurred }\end{array}$ \\
\hline Social Care & An attitude where someone likes to help others who need it \\
\hline Responsibility & An attitude that exists in a person to carry out obligations that must be done \\
\hline
\end{tabular}

Source: Zarkasi, 2018

Madrasah Ibtidaiyyah, or commonly known as MI, which is a form of formal education that is equivalent to Elementary Schools (SD) but in MI education emphasizes religious material in order to form good character for students in accordance with Islamic law since early. In the learning curriculum contains 70\% of religious subjects and 30\% are general subjects (Pratama, 2019). The principle of good moral formation for a child in a Madrasah aims to form a good personality, behave honestly, respect, cherish and respect others. Moral education should begin with the intention and orientation in education, which is a way to make a difference between man and his God.

One of the character building or character of a child to be a moral child is a routine activity that is an activity carried out at all times continuously (Istiqomah). Some examples of routine activities at Madrasah Ibtidaiyyah now are the habit of reading the Qur'an before learning begins midday prayers and praying before and after learning begins (Karim, 2016). In addition to the traditional activities mentioned above, students are also required to follow the regulations of educational institutions such as using uniforms that have been determined according to school days, wearing shoes in accordance with the provisions and not being late in participating in learning activities in class.

In addition to habituation, activities there are also exemplary activities where a teacher is a role model for his students (Anwar, 2014). The teacher exemplifies how to do a good attitude and / or behavior in accordance with religious rules and norms. Because for young children what they see, what they notice and what they hear, young children will follow.

According to Athiyah al-Abrasi that the purpose of moral education or character is to form people who are virtuous, have a strong will, polite in speech and deeds, noble in behavior and civilized. With a mirror of good values in one's attitude and behavior, a good personality will appear as a Muslim (Johansyah, 2011).

The core of the function of character education in Madrasah is to form a nation that is strong, has noble character, has morals, can be tolerant, works together, has a patriotic spirit and develops dynamically, oriented in science and technology, all of which are imbued by faith and piety to God is based on Pancasila. The existence of character education in schools is also so that students or children are able to develop good potential, choose their own national culture and filter out foreign cultures according to good values, and also participate and be responsible for the potential of citizens (Khalimah, 2017).

2. Non-Formal Education

Non-formal education is one of the educational services that are as a substitute, supplementary or complementary to formal education. His vision is the same as formal education, which is as a medium of learning or lifelong education. This refers to Law Number 20 of 2003 that "The education channel consists of 
formal, non-formal and informal education that can enrich and complement each other". By referring to existing national education standards, the results obtained from non-formal education can also be synchronized with formal education. To be able to meet the learning needs of the community, the role of non-formal education units becomes strategic.

Non-formal education is defined in all learning processes outside of formal educational institutions or other than education originating from schools. However, this education also has levels that are set autonomously from the non-formal institutions. Being an educational institution outside of education in schools does not make non-formal education wither and easily carried by the wind. The strict and clear provisions to be applied differ depending on the institution that formed it. This education is no less important than formal education or commonly understood in terms of school benches. Both types of education become an inseparable unity in the learning process.

The existence of education with noble character is very important not only to equip oneself in terms of practicing religious values, but also important in bringing students to become human beings who are virtuous (noble character), so it is necessary to discuss the influence of education in the formation of morals or the character of students.

Actually non-formal education has a big role as an agent for personal and social development (social transformation). Every person (individual) always lives in context with the community group, where they live. Education that is influenced by the view of progressivism sees the purpose of education as being dual, namely increasing individual self-development and at the same time improving better social life. If non-formal education is seen as community education, the form, purpose and activities of non-formal education should touch all dimensions of community life, as the concept of lifelong education emphasizes that all life activities can be interpreted as learning or educational activities (Kuntoro, 2006).

As for the benefits of attending non-formal education, such as the following: Development of selfpotential, ie time outside school hours and flexible but directed rules make non-formal education have its own role to develop the potential of each individual who follows it. Everyone will feel more comfortable and can maximize their talents through this unofficial education. All talents will be honed so that it will indirectly increase the quality of human resources created.

The approach does not stop at developing self-potential. Deeper than that this kind of education is also intended to be a wider network of socialization. Many new people will be known when attending education in informal institutions. A strong brotherhood forms a compassionate, friendly and environmentally sensitive person. The habit of socializing with stout people will make individuals grow more confident.

Familiar examples of non-formal education in people's lives. There are many types of non-formal education in today's society. People are required to be dynamic in keeping with the development of the times in today's life. Become thirstier for additional knowledge and skills, which can taste and maintain the talents, they have. These types of education that are widely known, including:

a) Course

Additional education programs other than at this school have become quite popular. The courses generally provide material that is development skills. Development here does not only represent one area, but all fields of development. Like the field of art, many courses are offered with many kinds such as music, drama, dancing and painting. In the field of sports, and daily activities such as driving, sewing and cooking. All of that is part of non-formal education.

b) Student Guidance

The deepening of the material while at school can be assisted through the tutoring program. This program makes each individual more understand, understand and have more knowledge when procuring classes outside school hours. Because tutoring can provide deeper knowledge for a study method.

c) Madrasa and Qur'an Education Park

This educational institution is more associated with religious educational institutions. Not only education in the form of non-religious knowledge. This education is an appropriate tool in developing character. The creation of a virtuous and loving generation among people is the real goal of the existence of madrasa institutions. More specific knowledge about religion becomes a special differentiator with 
other educational institutions. Many things from education that we understand as a form of selfactualization that is the right for every life. So participating in many extra activities will make a special point in forming a reliable person who is knowledgeable and has a great social spirit.

d) Mosque

Formerly the mosque was a home for worship and madrasa to explore knowledge, where Muslims meet and depart. It was there that they knew each other to love each other. From there they gather spiritual provisions, the light of knowledge, and the strength of faith. That's where their hearts are always tethered, and that's where their souls always return. The mosque they love more than their homes and possessions. They never feel bored to linger in it. They never feel bored to always visit it even though the distance stretches blocking it. They always expect the reward of every step they take. Take advantage of every time they spend in it, and compete to come immediately. Like the word of Allah SWT in AlQur'anul Karim letter At-Taubah verse 18 which means: "The only people who believe in the mosque of God are those who believe in Allah and the next day, and (still) perform prayers, perform zakat and not be afraid (to whatever) except to Allah, then hopefully they are among those who are guided' (Q.S. At Taubah: 18) (Departemen Agama RI, 2007).

The prosperity of the mosque by making the mosque the center of Islamic education is as much as the functioning of the mosque during the time of the Prophet that is also to educate generations of Islam. The mosque is like a lighthouse, where all knowledge is centered, then spreads in all directions. One way to create a forum for Islamic education, the mosque must have activities that can attract worshipers in that place. One example of an activity is discussion, which serves to increase knowledge for the congregation. Then it could also hold a youth meeting, which is one of the next generations to prosper the mosque (Muhtarom, 2012).

Education in the community is not only formal-based but there is also non-formal education and this is usually often held in mosques. Besides being used as a place of worship, a mosque can also be used as a place of religious study, the aim of which is to provide an understanding of Islamic values that are minimal in formal schools. The purpose of religious knowledge is conveyed to make children have a good personality that is akhlakul karimah. The morals of children are fostered and enhanced through mosque-based education, namely education where the material is about religion taught at the mosque (Saputra, 2019).

3. Differences in formal education and non-formal education

Formal education is a systematic, structured, multilevel activity starting from elementary school to tertiary level and equivalent, including academic and general oriented study activities, specialist programs, and professional training carried out in continuous time. Formal education is a structured and tiered education pathway, consisting of basic education, secondary education, and higher education. While nonformal education is education outside the formal education pathway that can be implemented in a structured and tiered manner. In addition, the results of non-formal education are valued equivalent to the results of formal education. Non-formal education includes life skills education, early childhood education, equality education and others.

4. The importance of formal and non-formal education

No matter how you take this education, as long as you want to be serious in living it, it will have a big impact on the future of yourself and others. Therefore, with education a person will be able to organize his future wisely, and can think more critically in solving a problem that occurs in his life. In the growth and development of community, life needs to be raised awareness of the importance of education and community encouragement to participate actively in the educational process. Starting from the problems faced, education in and outside the school trying to find answers by tracing the existing educational patterns. So many important things are obtained in understanding the meaning of education. Therefore, we should begin to realize how important education is for the survival of the future. In addition, as educated humans, we should want to understand that very well. 


\section{Conclusion}

Education is a conscious effort of humans in increasing knowledge about everything that exists in the natural surroundings and something that will be used as provisions in the life he will go through. Education starts from the process of learning and accessing knowledge and then receives and manages the information to be applied in everyday life. The educational environment itself has three kinds of networks namely: formal education, non-normal education and informal education. In interaction in the individual society must have ethics, manners and morals. To get the stock of learning starts from nonformal education that is embedded in the surrounding environment, because the characters that appear in students cannot only be obtained from formal education. However, with all the components of education that exist, although the three educations are different but they complement each other's existing elements and affect the success of education, persuasion, and character building of students.

\section{References}

A. Kuntoro, Sodiq. 2006. "Pendidikan Non Formal (PNF) bagi Pengembangan Sosial." Jurnal Ilmiah VISI PTK-PNF 1(2). Ahmad, Darlis. 2017. "Hakikat Pendidikan Islam: Telaah antara Hubungan Pendidikan Informal, Non Formal dan Formal". Jurnal Tarbiyah 24(1): 94-95

Anu, Nur Aini. 2014. "Pendidikan Karakter untuk Siswa SD dalam Perspektif Islam.” Jurnal UPI 1(1): 52.

Anwar Sumarsih. 2014. "Pendidikan Karakter di Madrasah Ibtidaiyyah Modern Sahid." Jurnal Edukasi 12(3): 333.

Departemen Agama Republik Indonesia. 2007. Al-Qur'an dan Tarjamahnya Special For Women. Bandung: Syaamil Al-Qur’an.

Eddy, Saputra. 2019. "Alternatif Pendidikan Non Formal dalam Meningkatkatkan Akhlak PadaAnak melalui Pendidikan Berbasis Masjid. Jurnal SAP (Susunan Artikel Pendidikan) 4(2): 143.

Enoh Khambali. 2016. "Implementasi Pembentukan Karakter pada Peserta Didik di MI Asih Putera Kota Cimahi”. Ta'dib Jurnal Pendidikan Islam 5(1): 66.

Hamdi, Abdul Karim. 2016. "Pendidikan Karakter di Madrasah Ibtidaiyyah.” Jurnal Elementari 2 (2).

Johansyah. 2011. "Pendidikan Karakter dalam Islam." Jurnal Ilmiah 10(1): 95.

Mahmud. 2011. Pemikiran Pendidikan Islam. Bandung: CV Pustaka Setia.

Nur, Khalimah. 2017. "Penguatan Pendidikan Karakter di Madrasah". Jurnal Kependidikan 5(2): 214

Rizki, Amalia. 2019. Pemanfaatan Masjid Sebagai Pusat Pendidikan Islam Nonformal (Studi Kasus Di Masjid Al-Jami’ Plupuh Kabupaten Sragen Tabun 2019). Skripsi. IAIN Salatiga.

Rizqun, Hanifah Muhtarom. 2012. Pemanfaatan Masjid Sebagai Pusat Pendidikan Islam Non Formal. Skripsi. Universitas Muhamadiyyah Surakarta.

Robiatul, Awwaliyah and Hasan Baharun. 2018. "Pendidikan Islam dalam Sistem Pendidikan Nasional (Telaah Epistemologi terhadap Problematika Pendidikan Islam)." Jurnal Ilmiah Didaktika 19(1).

Suhada. 2017. Lingkungan Pendidikan Dalam Perspektif Al-Qur'an. Jurnal Al-Hikmah 13(1): 3-5.

Yoga, Anjas Pratama. 2019. "Integrasi Pendidikan Madrasah dalam Sistem Pendidikan Nasional (Studi Kebijakan Pendidikan Madrasah di Indonesia). Jurnal Pendidikan Islam 10(1): 104-105

Zarkasi, Taqiudin Al-Kuusairi. 2018. "Penguatan Pendidikan Karakter di Madrasah (Perpres No 68 Tahun 2017). Jurnal AlMuta'aliyah STAI Darul Kamal NW Kembang Kerang 1(3): 8-9. 